\title{
Who Wants to Return Home? A Survey of Sudanese Refugees in Kakuma, Kenya
}

\author{
Roy J. Eidelson and Rebecca Horn
}

\begin{abstract}
With the goal of better understanding some of the psychological factors related to refugees' desire to return home, surveys were administered to 235 South Sudanese refugees living in the Kakuma Refugee Camp in Kenya. Respondents were asked about how much they wanted to return to Sudan, their emotional reactions about returning, their views on the prospects for peace, their expectations regarding how they would be received upon return, and their concerns about specific challenges they might face. In addition, they completed an inventory measuring their personal beliefs about issues in five domains: vulnerability, injustice, distrust, superiority, and helplessness in regard to prospective returnees to Sudan. A large majority was very eager to repatriate. Individual differences in attitudes toward returning were significantly linked to the strength of their beliefs in the five domains. Stronger beliefs about vulnerability, injustice, distrust, and helplessness were associated with more negative perceptions of return, while a stronger belief about returnee superiority was correlated with a more favourable perspective on repatriation.
\end{abstract}

\section{Résumé}

Dans le but de mieux comprendre quelques-uns des facteurs psychologiques liés au désir des réfugiés de retourner chez eux, des enquêtes ont été conduites auprès de 235 réfugiés originaires du sud Soudan et vivant dans le camp de réfugiés de Kakuma, au Kenya. On posa aux répondants des questions sur l'intensité de leur désir de retourner au Soudan, leurs réactions émotionnelles par rapport à toute la question du retour, leur point de vue sur les perspectives pour la paix, leurs attentes quant à la façon dont ils seraient reçus au retour, et leurs préoccupations quant aux défis spécifiques qui pourraient les con- fronter. En plus, ils complétèrent aussi un inventaire de personnalité permettant d'évaluer leurs croyances personnelles sur des questions relatives à cinq domaines : la vulnérabilité, l'injustice, la méfiance, la supériorité, et le sentiment d'impuissance par rapport aux éventuels candidats au retour au Soudan. La grande majorité était très désireuse de rentrer au pays. Les différences individuelles dans les attitudes par rapport au retour étaient étroitement liées à l'intensité de leur croyance dans les cinq domaines. Une croyance plus forte dans la vulnérabilité, l'injustice, la méfiance, et le sentiment d'impuissance était associée à des perceptions plutôt négatives sur le retour, alors qu'une croyance plus forte quant à la supériorité du réfugié revenant chez lui était corrélée avec une perspective plus favorable sur le retour.

\section{Introduction}

The plight of refugees and other people displaced from their homes by uncontrolled violence or deliberate ethnic expulsion has been well documented and has received increasing attention from scholars, practitioners, and the international community over the past decade. ${ }^{1}$ Millions of these refugees find shelter in large camps run by UNHCR and collaborating NGOs, where they may "temporarily" reside for years and sometimes for decades. From this distance, across their country's borders, refugees often dream of someday returning, in part because, despite the events that may have precipitated their flight, feeling "at home" is viewed as a comfort that only their homeland can provide. ${ }^{2}$

But numerous researchers have documented how repatriation often proves to be significantly less rewarding and far more disillusioning than the resilient refugees who return home had anticipated ${ }^{3}$ - due to a variety of factors including resentment from stayees, being perceived as outsiders, disinterest in their stories, stressful economic circumstances, and unexpected changes during their time 
away. ${ }^{4}$ In short, as Harrell-Bond and Gatson have observed: "Because the return is so strongly associated in the minds of exiles with the end of a traumatic period, the unexpected differences and difficulties can make going 'home' even more painful than the original exile."5

A particular setting where many of these issues and dynamics are currently salient is the Kakuma camp in Kenya, temporary haven to thousands of refugees from southern Sudan. During 2004-2005, UNHCR developed a repatriation plan to assist those refugees who want to return home. With this opportunity on the horizon, in the fall of 2005 we surveyed a sample of these refugees in Kakuma to assess their desire to return to Sudan, their emotional reactions at the prospect, their view of the ongoing peace process, the reactions they anticipated from stayees in Sudan, and the logistical challenges they expected to encounter. In addition, we were especially interested in how certain beliefs might bear upon their preferences and their perceptions of the road that lay ahead. Before describing these beliefs, some background on the Kakuma Refugee Camp is warranted.

\section{Kakuma Refugee Camp and Its South Sudanese Refugees}

Kakuma refugee camp was originally established for the 12,000 Sudanese minors who arrived in 1992, and since that time they have been joined by refugees from other nationalities and by thousands more Sudanese. Some have been resettled to third countries, such as the United States, Australia, and Canada, but many have been living in Kakuma for more than ten years. Those who came as children have been educated and have grown to adulthood in Kakuma; many children have been born here and have never seen Sudan.

The opportunities for refugees in Kakuma to improve their lives are limited. Kenyan government policy dictates that refugees are not allowed to live freely, but must stay in one of two camps (Kakuma or Dadaab). In Kakuma, refugees are not allowed to keep animals, since this is likely to increase conflict between the refugees and the local Turkana people. The semi-arid environment is not conducive to growing crops. It is possible for refugees to start small businesses, if the capital is available (either through a loan from an NGO or with money sent by family abroad). However, the market is finite because Kakuma is in a very isolated area and the majority of customers are other refugees, a small number of NGO staff, and local Kenyans. All NGOs in the camp "employ" refugees, but due to Kenyan laws prohibiting employment of refugees, they are engaged on a voluntary basis and then paid an "incentive," which is far lower than a wage would be for a Kenyan in an equivalent job.

Life in Kakuma, therefore, is hard, and the Sudanese community in the camp has placed a great deal of hope in the Sudanese Comprehensive Peace Agreement (CPA), which was signed on 9 January 2005. Many expect that this will enable them to leave Kakuma to return to a new and peaceful Sudan, where they will have opportunities to live more comfortable and fulfilling lives. Agencies such as UNHCR are also anticipating that most Sudanese refugees in Kakuma (as well as other parts of Kenya, Uganda, Ethiopia, Central African Republic, and the Democratic Republic of Congo) will indeed return home. This process is not, however, expected to occur rapidly, because South Sudan currently lacks many basic facilities such as schools, hospitals, and roads, and much of the land is contaminated with mines.

UNHCR has developed a repatriation plan to assist those refugees who want to return. In addition to assisting returnees logistically (e.g., providing transport), the plan includes providing information, non-food items (e.g., cooking pots, blankets), and protection to those returning; registering, monitoring, and tracking returnees; and ensuring there is the capacity to respond to emergencies. The assisted voluntary repatriation process was anticipated to begin once the rainy season ended in Sudan (i.e., from October 2005 onwards), and to continue until May 2006, when the rains begin again and transportation becomes impossible due to the lack of paved roads. In July 2004 UNHCR anticipated that 30,000 Sudanese refugees would return from Kakuma in the eighteen months after the signing of the CPA. ${ }^{6}$ However, it appears that this was overly optimistic. UNHCR revised its estimate with the expectation of 10,000 refugees being repatriated by the time the rains were to begin in May 2006.

The downward revision in large measure reflects recent political changes in Sudan resulting from the untimely death of Dr. John Garang de Mabior, the charismatic and influential leader of the Sudanese People's Liberation Army (SPLA). Garang was killed in a helicopter crash on 30 July 2005, three weeks after being sworn in as the first vice-president of the new Sudan. As the leader of the SPLA, Garang led the rebellion against the Khartoum government for twenty-two years. He was an exceptional politician, and one of the few senior southerners who genuinely believed in the concept of a united Sudan. For many South Sudanese, hopes and aspirations for a peaceful and prosperous future for their country were very much bound up with the figure of John Garang. The resulting sense of uncertainty has apparently led to reluctance amongst many Sudanese in Kakuma to return home immediately; instead, they want to wait and see how things develop in their homeland before returning. In response to this uncertainty, UNHCR Kakuma organized "goand-see" missions, in which groups of Sudanese community leaders from the camp were taken to South Sudan to see the situation for themselves, and were then brought back to 
Kakuma, where they were expected to pass on the information to members of their communities. However, the news that the facilities in Sudan were minimal did little to reassure refugees that the time was right for them to return.

As a result of this combination of factors, the launch of the assisted repatriation process on 17 December 2005 saw only 131 refugees return, some by plane and some by bus, to Kapoeta, Chukudum, and Bor. According to UNHCR, 1,600 refugees have registered for return to Sudan as soon as possible, and they still expect to repatriate 10,000 from Kakuma by May 2006 and to have repatriated all Sudanese refugees within the next four years. However, it is worth noting that in the same week that 131 refugees were officially repatriated from Kakuma, over 200 were received from Sudan. South Sudanese refugees continue to come to Kakuma in significant numbers, primarily due to hunger but also due to militia attacks in the south. Kakuma also receives a number of refugees from Darfur.

\section{The Role of Refugees' Core Beliefs in Deciding Whether to Return Home}

Eidelson and Eidelson have proposed that certain beliefs are particularly influential because they operate simultaneously as core beliefs fundamental to the daily existential experiences of individuals and as collective worldviews pivotal to the central concerns and shared narratives of groups. ${ }^{7}$ They identify five specific content domains that meet this dual standard: namely, beliefs about vulnerability, injustice, distrust, superiority, and helplessness. The extent to which these deeply held beliefs are healthy and functional depends in large measure on whether or not they are accurate reflections of institutional realities and other real-world conditions. Whether from the perspective of an individual or a group, each of the five domains represents a personal or collective arena where beliefs can often encourage the exaggeration or underestimation of the risks and burdens currently faced or lying ahead.

In our survey we were interested in determining whether this five-belief framework would be useful in understanding how the Sudanese refugees in Kakuma felt about the prospect of returning home and how they perceived the situation that would await them there. Since an extensive discussion of these five domains is available elsewhere, ${ }^{8}$ here we provide only a brief summary of the central features of each, with a particular focus on its relevance for refugees at Kakuma (based in part on observations from the second author's work in the camp over the past three years). Clearly, exploring the potential impact of these beliefs can prove valuable only if they have meaning and relevance within the specific social and cultural context to which they are applied. ${ }^{9}$

\section{Vulnerability}

The vulnerability belief, whether applied to one's personal world or to the experience of one's group, is characterized by the conviction that the world is a dangerous and risky place, where safety and security are difficult to obtain and catastrophic loss lurks on the horizon. ${ }^{10}$ It often includes a tendency to focus on the likelihood of dire outcomes, which at the group level may originate in perceptions of the ingroup's history as one of misery and oppression. As such, current peril and an uncertain future would appear to be defining features of the experience of many refugees and the groups with which they identify. In the Kakuma context, Sudanese refugees regularly describe themselves as under attack, not only by the northern Sudanese government but also by other groups in South Sudan. For example, the Dinka and Nuer tribes have a long history of conflict, which has continued to some degree in the camp, and each group perceives the other as likely to harm them if an opportunity arises.

\section{Injustice}

The injustice belief is based on the individual's perceptions of being personally mistreated by others or the view that in-group members receive undeserved, substandard, and unjust outcomes, perhaps due to a biased or rigged system created by a more powerful outgroup. ${ }^{11}$ Such beliefs typically heighten identification and allegiance toward the ingroup, ${ }^{12}$ and they can mobilize powerful and violent collective insurgencies. ${ }^{13}$ The injustice mindset is frequently linked to a historical perspective that emphasizes past episodes or periods of abuse and exploitation at the hands of others, which again can be a very prominent element of the refugee experience. In the Kakuma context, this belief is held most strongly by South Sudanese refugees in relation to the northern Sudanese government, which they believe has oppressed and exploited them for decades. However, such convictions are also held by some South Sudanese groups about each other. For example, at the time of writing, Nuer, Dinka Bor, and Dinka Bar el-Ghazal leaders in South Sudan are negotiating to resolve a conflict stemming from the Nuer group's belief that they are being treated unjustly in terms of the number of ministerial posts given to members of their tribe compared with those given to the other two groups.

\section{Distrust}

The distrust belief focuses on the presumed hostility and malicious intent of other individuals or other groups. In reference to the personal world, this mindset may range from a predisposition toward suspicion and anticipated deceit to outright paranoia. At the group level, the conviction that outsiders harbour malevolent designs toward the 
in-group is sufficiently widespread that "dishonest" and "untrustworthy" are considered to be central elements in the universal stereotype of outgroups. ${ }^{14}$ Here too, refugees would seem to have a particularly strong basis for developing a distrust mindset. In regard to refugees in Kakuma, it is important to recall that there have been previous peace agreements in Sudan, all of which have been broken. Most notably, the 1972 Addis Ababa Accord was progressively breached by the northern government, which was intent on controlling the oil fields in the south. Their introduction of Sharia law and other steps towards Islamization of the south triggered the resumption of the war in 1983. For most South Sudanese, therefore, it is difficult to believe in the northern government's commitment to the peace agreement, and there is great distrust of the northern regime generally. ${ }^{15}$

\section{Superiority}

The superiority belief revolves around the conviction that the individual or the in-group is morally superior, chosen, entitled, or destined for greatness - and the corresponding view that others are contemptible, immoral, and inferior. ${ }^{16}$ At the group level, this mindset can be used to explain, legitimize, and ruthlessly enforce in-group status advantages ${ }^{17}$ - or to advance the claim that current deprivations are temporary and inappropriate. It is this latter perspective that may capture a potentially key aspect of some refugee groups' understanding of their circumstances. Anecdotally, among refugees at Kakuma negative perceptions of members of other groups were more evident than was a narcissistic view of their own group's worth. For example, Dinka and Nuer refugees often talk about the negative characteristics of the other group; they are also very critical about the Muslim religion and lifestyle of the northern Sudanese.

\section{Helplessness}

Finally, the helplessness belief refers to the conviction that the individual or the in-group is unable to favourably influence or control events and outcomes. ${ }^{18}$ Even when it does not accurately represent objective reality, this belief tends to be self-perpetuating because it diminishes motivation. ${ }^{19}$ At the group level, since an effective social movement is inherently risky and depends upon the promise of some reasonable likelihood of success, organized political mobilization is severely hampered when group members perceive their in-group to be helpless to alter its circumstances. Although one might imagine that refugees could be particularly prone to see themselves as helpless, anecdotally this does not seem to be the case in regard to Kakuma's South Sudanese refugees. Rather, most of them appear to take considerable pride in the groups to which they belong, whether a clan group, a tribal group, or the larger group of "south Sudanese," and they believe that these groups have power and efficacy. Indeed, in many ways the helplessness belief appears to be antithetical to Sudanese culture.

\section{The Personal Beliefs of Sudanese Refugees about Their Group}

Eidelson and his colleagues have provided a further elaboration of this five-domain model..$^{20}$ Of particular relevance here, they have emphasized how individual differences in members' personal beliefs about their in-group can be potentially important factors in explaining variation in their preferences, choices, and perceptions of the group's collective circumstances. Applying this framework to the Kakuma setting, we hypothesized that differences among the Sudanese refugees in the extent to which they believed their group would be vulnerable, mistreated, in need of a distrustful posture, superior, or helpless if they returned home would predict how they would view the prospect of repatriating. In particular we expected that stronger beliefs about the group in the vulnerability, injustice, distrust, and helplessness domains would be associated with a diminished desire to return to Sudan and with less favourable assessments of what life in Sudan would be like, while stronger convictions of in-group superiority would be linked to greater eagerness to repatriate and a more positive outlook on what the future there might hold.

Our interest in examining these specific hypothesized relationships and in evaluating the five-domain model more generally was motivated by the recognition that the psychological and informational bases upon which refugees make repatriation decisions can have very important implications for their welfare and future adjustment. Any framework that facilitates the identification of key issues and improves the process for prioritizing, organizing, and discussing available information about "home" (or other potential destinations) within the context of core concerns should be of value to the prospective returnees themselves and to the humanitarian aid workers striving to best assist and represent them.

\section{Method}

\section{Participants}

Participants $(N=23)$ were recruited from all areas of the Kakuma camp. All were Sudanese and Christian, and 68.1 per cent were male (although the gender balance was closer to 60 per cent male in the camp as a whole). The participants' ages ranged from sixteen to eighty-five $(M=31.43, \mathrm{SD}=10.97)$, with no significant age differences between the men and the women (for those sixteen and older, the respondents' age distribution closely mirrored that of the camp for the female participants, but the proportion of young males in the camp 
was under-represented in the survey sample). Twenty-two tribes were represented, with the largest number of participants describing themselves as Dinka (62.1 per cent). Other significant groups were Nuer ( 8.5 per cent), Didinga ( 7.7 per cent), and Acholi (5.1 per cent). The other eighteen tribes comprise the remaining 16.6 per cent of the sample.

The refugees surveyed had been living in Kakuma for between one and fifteen years $(M=9.31, S D=3.54)$, with males having spent more time in the camp than women $[t(233)=2.09, p=.037]$. Of the participants, 90.6 per cent had at least one other relative also living in the camp $(M=$ $6.27, S D=5.18)$. The number of years' schooling ranged between zero and nineteen $(M=8.64, S D=4.65)$, with 85.0 per cent of the respondents having had some level of formal education. On average the women had received significantly less schooling than the men $[\mathrm{t}(232)=-8.78, \mathrm{p}<.001]$. The majority (60.4 per cent) did not have paid employment. Of those who were employed, 88.2 per cent were male and almost all were working for NGOs in the camp, as would be expected. They were engaged in a range of work, including teaching, health-related work, and social work or counsellling. Wages for those with paid employment ranged considerably, from 100 to 8,000 Kenyan shillings (approximately $\$ 1.40$ to $\$ 110)$ per month $(M=2,960 \mathrm{KES}, S D=945)$. Most NGOs in Kakuma pay 3,000 KES per month to their non-supervisory staff, and two-thirds of the employed participants in the sample earned this amount.

\section{Procedure}

Participants were recruited by refugees working with the Jesuit Refugee Service's Community Counseling program, which is managed by the second author. Fifteen community counsellors volunteered to assist with the data collection, and they were trained by the second author in issues relating to informed consent, sampling procedures, and the completion of the survey. The counsellors took the number of surveys they thought it would be possible to have completed by people in their communities (this varied between three and twenty-five). Each counsellor lives and works in a different community and different groups of potential participants were thereby enlisted. The counsellors were asked to try to recruit a group of people representative of their community in terms of gender, age (although none less than sixteen years old), education, and employment status.

The educational level of older refugees in Kakuma, who have not attended school in the camp, tends to be low, especially amongst women. Counsellors were therefore also trained in how to assist those unable to read the survey. Since in some cases it would be necessary to read each question to the participant, and in many other cases people would read very slowly, it was necessary to keep the survey relatively short. For the same reason, the items needed to be worded very simply, to ensure that they would be understood by all potential participants.

Once the training was completed, counsellors were given two weeks (24 October to 7 November 2005) to recruit participants and have them complete the surveys. At the end of that period, they submitted the completed surveys to the second author. The surveys were then qualitychecked, and any discrepancies or missing data discussed with the counsellor responsible and corrected if possible. Data entry was performed by the second author.

\section{Survey Measures}

Unless otherwise specified, all of the items assessing the refugees' attitudes about returning home to Sudan were measured using the jerry can image technique described below and then coded using a scale of $O$ ( $I$ do not agree) to 3 (I agree strongly).

Personal Beliefs about the Sudanese Refugee Group in Kakuma. The Individual-Group Belief Inventory (IGBI) developed by the first author was adapted to measure the respondents' beliefs about their refugee group. ${ }^{21}$ In its standard form, the IGBI measures each of the five belief domains - vulnerability, injustice, distrust, superiority, and helplessness - at each of three levels of analysis (personal beliefs about the personal world, personal beliefs about the in-group, and personal perceptions of the in-group's collective worldviews) - using a five-point Likert-type scale ranging from Strongly Disagree (1) to Strongly Agree (5). In this survey we focused on one level of analysis only: personal beliefs about the in-group.

Several content and format changes were made in order to make the IGBI appropriate for use in the Kakuma context. First, we decided to modify the items so that they focused on beliefs about returning home to Sudan rather than on current circumstances at the camp. Second, based on the guidance of the second author and camp counsellors, the original IGBI item content was changed where necessary so that the language and ideas were readily comprehensible by this refugee sample. A first draft of the survey was shared with eight Sudanese community counsellors. The second author discussed each item with this group of community counsellors and those items thought to be confusing or unclear were revised by the counsellors into a format which they felt would be understood by potential participants. Third, the standard answer format for the IGBI was modified significantly. The respondents were asked to answer each item on the equivalent of a four-point scale: $I$ do not agree, I agree slightly, I agree, and I agree strongly. Answers were indicated by filling in different levels of a small jerry can image (an object very familiar to Kakuma refu- 
gees), so that filling the jerry can higher represented greater agreement with the item; this approach was modelled after a similar strategy described by Annan et al. and used in Uganda. ${ }^{22}$ This method necessitated eliminating the symmetrical bipolar continuum of the standard IGBI items because there was no way to represent conditions where there was less than no water in the jerry can ("I do not agree" corresponded to leaving the jerry can empty). The items used are listed in Table 1 (one of the three original helplessness items was not used because it was unexpectedly negatively correlated with the other two helplessness items).

\section{Table 1. Individual-Group Belief Inventory (IGBI) Items}

\section{Vulnerability}

- I believe that Kakuma refugees who return to Southern Sudan will not be secure.

- I believe that Kakuma refugees who return to Southern Sudan must be always alert for possible danger.

- I believe that Kakuma refugees who return to Southern Sudan will not be safe.

\section{Injustice}

- I believe other groups will often be unfair to Kakuma refugees who return to Southern Sudan.

- I believe Kakuma refugees who return to Southern Sudan will be blamed by other groups more than they should be.

- I believe that the good things done by Kakuma refugees who return to Southern Sudan will never be appreciated.

\section{Distrust}

- I believe Kakuma refugees who return to Southern Sudan should expect bad treatment from other groups.

- If given the chance, I believe that other groups will try to deceive Kakuma refugees who return to Southern Sudan.

- I believe Kakuma refugees who return to Southern Sudan generally should not trust other groups.

\section{Superiority}

- I believe Kakuma refugees who return to Southern Sudan will be better than other groups in their ways of doing things.

- I believe that Kakuma refugees who return to Southern Sudan will do better than other groups.

- I believe Kakuma refugees who return to Southern Sudan will contribute more to their communities than other groups.

\section{Helplessness}

- I believe that the future of Kakuma refugees who return to Southern Sudan will not be very good.

- I believe that what happens to Kakuma refugees who return to Southern Sudan will be in the hands of other groups.
Preference for Retuning Home, Resettlement, and Remaining in Kakuma. Three individual items each assessed the refugees' attitudes toward returning home to Sudan ("I want to return home to live in Sudan very much"), resettling elsewhere ("I want to be resettled in another country very much"), and staying in the Kakuma camp ("I want to remain and live in Kakuma very much").

Emotional Reactions to Returning Home. The respondents' comparative positive versus negative emotional reactions toward the prospect of returning home to Sudan were measured with four items: "When I think about returning to live in Sudan I feel happy," "When I think about returning to live in Sudan I feel frightened" (reversescored), "When I think about returning to live in Sudan I feel angry" (reverse-scored), and "When I think about returning to live in Sudan I feel sad" (reverse-scored).

Peace Prospects in Sudan. The respondents' view of the prospects for peace in Sudan was measured with four items: "I strongly support the current peace agreement in Sudan," "There will now be peace in Sudan for a very long time," "All the people of Sudan can learn to live together in peace," and "The people of Southern Sudan will prosper now that there is peace."

Hostile Treatment upon Return. The respondents' sense of whether they would be viewed and treated negatively upon their return to Sudan was measured with three items: "If I return to Sudan, I will be welcomed back by those in my family and tribe who stayed in Sudan during the conflict" (reverse-scored), "If I return to Sudan, those in my family and tribe who stayed in Sudan during the conflict will treat me unfairly," and "If I return to Sudan, I will be seen as an 'outsider' by those in my family and tribe who stayed in Sudan during the conflict."

Concerns over Returning Home to Sudan. The respondents' concerns over returning to Sudan were measured using six items: "When I think about returning to Sudan, I am very worried about security," "When I think about returning to Sudan, I am very worried about mines," "When I think about returning to Sudan, I am very worried about the roads and transportation," "When I think about returning to Sudan, I am very worried about education," "When I think about returning to Sudan, I am very worried about how I will support myself and my family," and "When I think about returning to Sudan, I am very worried about how I will get clean water." These are familiar areas of concern for refugees, and this specific list was drawn from a 2004 UNHCR report on repatriation to Sudan that identified them as primary concerns for returning refugees. ${ }^{23}$ 


\section{Results}

Table 2 presents the survey items related to returning home to Sudan, including some items that were not used in constructing the criterion measures described above. The percentage figures in the table represent the combined percentage of participants who responded "agree" or "strongly agree" to each item. Table 3 presents the means and standard deviations for the variables used in this study, as well as the Cronbach alphas for the composite measures.

Table 2. Combined Percentage of "Agree" and "Strongly Agree" Responses to Key Survey Items

\begin{tabular}{|c|c|}
\hline Survey Item & $\begin{array}{c}\% \\
\text { Agreement }\end{array}$ \\
\hline I want to return home to live in Sudan very much. & 73.6 \\
\hline $\begin{array}{l}\text { I want to be resettled in another country very } \\
\text { much. }\end{array}$ & 37.0 \\
\hline I want to remain and live in Kakuma very much. & 6.8 \\
\hline $\begin{array}{l}\text { I have been following the news about Sudan very } \\
\text { closely. }\end{array}$ & 70.6 \\
\hline $\begin{array}{l}\text { I strongly support the current peace agreement in } \\
\text { Sudan. }\end{array}$ & 77.4 \\
\hline $\begin{array}{l}\text { There will now be peace in Sudan for a very long } \\
\text { time. }\end{array}$ & 43.8 \\
\hline $\begin{array}{l}\text { All the people of Sudan can learn to live together } \\
\text { in peace. }\end{array}$ & 65.1 \\
\hline $\begin{array}{l}\text { I am willing to forgive the people who have } \\
\text { harmed me and my people. }\end{array}$ & 63.0 \\
\hline $\begin{array}{l}\text { The people of Southern Sudan will prosper now } \\
\text { that there is peace. }\end{array}$ & 60.4 \\
\hline $\begin{array}{l}\text { The past years have been more difficult for } \\
\text { Sudanese refugees than for those who stayed in } \\
\text { Southern Sudan. }\end{array}$ & 47.6 \\
\hline $\begin{array}{l}\text { It is important to identify and punish the } \\
\text { perpetrators involved in the Sudanese conflict. }\end{array}$ & 51.5 \\
\hline I trust the new government in Sudan. & 29.4 \\
\hline $\begin{array}{l}\text { If I return to Sudan, I will be welcomed back by } \\
\text { those in my family and tribe who stayed in Sudan } \\
\text { during the conflict. }\end{array}$ & 78.7 \\
\hline $\begin{array}{l}\text { If I return to Sudan, those in my family and tribe } \\
\text { who stayed in Sudan during the conflict will treat } \\
\text { me unfairly. }\end{array}$ & 19.6 \\
\hline $\begin{array}{l}\text { If I return to Sudan, I will be seen as an "outsider" } \\
\text { by those in my family and tribe who stayed in } \\
\text { Sudan during the conflict. }\end{array}$ & 29.5 \\
\hline
\end{tabular}

\begin{tabular}{|c|c|}
\hline $\begin{array}{l}\text { I intend to return home to live in Sudan sometime } \\
\text { within the next year. }\end{array}$ & 41.3 \\
\hline $\begin{array}{l}\text { When I think about returning to live in Sudan I } \\
\text { feel happy. }\end{array}$ & 73.2 \\
\hline $\begin{array}{l}\text { When I think about returning to live in Sudan I } \\
\text { feel frightened. }\end{array}$ & 41.3 \\
\hline $\begin{array}{l}\text { When I think about returning to live in Sudan I } \\
\text { feel angry. }\end{array}$ & 17.0 \\
\hline $\begin{array}{l}\text { When I think about returning to live in Sudan I } \\
\text { feel sad. }\end{array}$ & 20.9 \\
\hline $\begin{array}{l}\text { When I think about returning to Sudan, I am very } \\
\text { worried about security. }\end{array}$ & 77.0 \\
\hline $\begin{array}{l}\text { When I think about returning to Sudan, I am very } \\
\text { worried about mines. }\end{array}$ & 87.2 \\
\hline $\begin{array}{l}\text { When I think about returning to Sudan, I am very } \\
\text { worried about the roads and transportation. }\end{array}$ & 80.4 \\
\hline $\begin{array}{l}\text { When I think about returning to Sudan, I am very } \\
\text { worried about education. }\end{array}$ & 80.9 \\
\hline $\begin{array}{l}\text { When I think about returning to Sudan, I am very } \\
\text { worried about how I will support myself and my } \\
\text { family. }\end{array}$ & 68.5 \\
\hline $\begin{array}{l}\text { When I think about returning to Sudan, I am very } \\
\text { worried about how I will get clean water. }\end{array}$ & 70.6 \\
\hline $\begin{array}{l}\text { It is safer for me to live in Kakuma than to live in } \\
\text { Sudan. }\end{array}$ & 33.2 \\
\hline I can earn a better living in Kakuma than in Sudan. & 23.0 \\
\hline The schools are better in Kakuma than in Sudan. & 85.5 \\
\hline $\begin{array}{l}\text { Hospitals and medical care are better in Kakuma } \\
\text { than in Sudan. }\end{array}$ & 68.1 \\
\hline $\begin{array}{l}\text { Women deserve greater freedom and rights than } \\
\text { they now have in Sudan. }\end{array}$ & 70.6 \\
\hline $\begin{array}{l}\text { There are big problems in Sudan between the } \\
\text { youth and the old. }\end{array}$ & 48.9 \\
\hline $\begin{array}{l}\text { I have a lot of contact with those refugees who } \\
\text { have already returned to Sudan. }\end{array}$ & 32.9 \\
\hline $\begin{array}{l}\text { I know a lot about what is going on right now in } \\
\text { Sudan. }\end{array}$ & 53.8 \\
\hline $\begin{array}{l}\text { I am very concerned about how the Northern } \\
\text { Sudanese will react if I return to Southern Sudan. }\end{array}$ & 62.6 \\
\hline $\begin{array}{l}\text { I am very concerned about how fellow South } \\
\text { Sudanese will react if I return to Southern Sudan. }\end{array}$ & 40.9 \\
\hline
\end{tabular}

Note. $N=235$. 
Table 3. Descriptive Statistics and Cronbach Alphas

\begin{tabular}{|c|c|c|c|}
\hline & $M$ & $S D$ & Alpha \\
\hline \multicolumn{4}{|l|}{ Personal Beliefs about the Refugee Group } \\
\hline Vulnerability & 1.47 & 0.76 & 0.54 \\
\hline Injustice & 1.26 & 0.75 & 0.57 \\
\hline Distrust & 1.30 & 0.79 & 0.59 \\
\hline Superiority & 2.40 & 0.66 & 0.64 \\
\hline lplessness & 1.05 & 0.84 & 0.43 \\
\hline \multicolumn{4}{|l|}{ Attitudes about Returning Home } \\
\hline I want to return home & 2.15 & 1.08 & - \\
\hline I want to be resettled & 1.19 & 1.25 & - \\
\hline Optimistic about peace in Sudan & 1.82 & 0.73 & 0.75 \\
\hline Expects hostility upon returning home & 0.77 & 0.77 & 0.84 \\
\hline More positive than negative emotions & 2.15 & 0.85 & 0.65 \\
\hline Worried about problems upon return & 2.18 & 0.67 & 0.78 \\
\hline
\end{tabular}

Note. $N=235$. All scales range from 0 (I Do Not Agree) to 3 (I Agree Strongly).

\section{Attitudes about Returning Home}

The vast majority of respondents reported that they wanted to leave Kakuma. Only 6.8 per cent either agreed or strongly agreed that they wanted to stay in the camp. It is also clear that they much preferred to return home to Sudan than to be resettled in some unspecified other country. 73.6 per cent agreed or strongly agreed that they wanted to return home, whereas a substantially smaller 37.0 per cent expressed a comparable level of support for being resettled elsewhere. Moreover, in a direct comparison of these two departure options, 62.6 per cent preferred Sudan to resettlement elsewhere, 11.1 per cent were indifferent between the two choices, and 26.3 per cent preferred resettlement to repatriation. It should be noted, however, that the percentage who reported that they actually expected to return home sometime in the next year ( 41.3 per cent) was much smaller than the percentage who wanted to return (73.6 per cent).

Overall, the respondent group had a positive perspective in regard to Sudan's future and their own lives if given the opportunity to repatriate. A large majority of the respondents reported a predominance of positive over negative emotions when they anticipated returning home: happy (73.2 per cent), fearful (41.3 per cent), angry (17.0 per cent), and sad (20.9 per cent). This divergence was even more apparent among those refugees eager to return (i.e., a response of "agree" or "strongly agree" on that item). A majority also had a favourable view of the prospects 7 for peace in Sudan despite the recent death of SPLA leader John Garang de Mabior: 60.9 per cent scored above the midpoint on the four-item peace prospects criterion measure (however, only 29.4 per cent expressed trust in the new Sudanese government). Similarly, only a small minority (18.7 per cent) scored above the midpoint on the three-item measure assessing whether the respondents expected a negative reception upon their return home. At the same time, large majorities did acknowledge worries in specific domains. Agreement or strong agreement over concerns about security, mines, roads, education, money, and water was reported by 77.0 per cent, 87.2 per cent, 80.4 per cent, 80.9 per cent, 68.5 per cent, and 70.6 per cent respectively. Based on these figures, it appears that the refugees were not naïve in their impressions of some of the challenges they would face upon returning to Sudan.

\section{Beliefs about the Refugee Group and Attitudes about Returning Home}

Table 4 presents the correlations among the key variables in the survey. It should be noted that all of the IGBI belief scales except for superiority were significantly correlated with each other, and that in general the criterion measures were correlated with each other as well. As the table indicates, at the level of zero-order correlations our hypotheses were consistently confirmed across all measures: stronger beliefs about group vulnerability, injustice, distrust, and helplessness were linked to a more negative outlook on repatriation, and a stronger group superiority belief was associated with a more positive perspective toward returning home. In addition, as one might expect, the five belief scales had exactly the reverse relationships to the respondents' desire to resettle elsewhere. It should be noted that desire to repatriate and desire to resettle were significantly negatively correlated with each other.

In light of these correlations, a separate regression analysis using the five IGBI scales as predictor variables was conducted for each of the repatriation-focused criterion measures in order to determine (1) how much explanatory power was provided by this combined set of beliefs and (2) whether each belief domain contributed uniquely to explaining individual differences in attitudes toward returning home. Table 5 presents the summary statistics for these models. Demographic variables were not included as covariates in these analyses; however, parallel regressions were performed including covariates and the results were comparable to those reported here.

The variable of primary interest was the single item assessing whether the respondents wanted to return home to Sudan. This regression model accounted for nearly onethird of the variance in the criterion measure, producing an 
Table 4. Inter-Correlations among Key Survey Variables

\begin{tabular}{|c|c|c|c|c|c|c|c|c|c|c|c|}
\hline & 1 & 2 & 3 & 4 & 5 & 6 & 7 & 8 & 9 & 10 & 11 \\
\hline 1. Vulnerability Belief & & .50 & .40 & -.05 & .44 & -.35 & .32 & -.43 & -.15 & .29 & .46 \\
\hline 2. Injustice Belief & & & .63 & .06 & .52 & -.37 & .29 & -.47 & -.26 & .45 & .34 \\
\hline 3. Distrust Belief. & & & & .08 & .47 & -.29 & .22 & -.43 & -.29 & .38 & .27 \\
\hline 4. Superiority Belief- & & & & & -.03 & .34 & .24 & .36 & .25 & -.22 & -.08 \\
\hline 5. Helplessness Belief & & & & & & -.27 & .27 & -.38 & -.19 & .36 & .25 \\
\hline 6. Want to Return Home & & & & & & & -.52 & .67 & .53 & -.44 & -.27 \\
\hline 7. Want to be Resettled- & & & & & & & & -.49 & -.28 & .39 & .27 \\
\hline 8. Primarily Positive Emotions & & & & & & & & & .54 & -.56 & -.34 \\
\hline 9. Good Prospects for Peace- & & & & & & & & & & -.34 & -.10 \\
\hline 10. Unfavourable Reception Likely & & & & & & & & & & & .30 \\
\hline 11. Concerned about Problems & & & & & & & & & & & \\
\hline
\end{tabular}

Note: $N=235$. For $|r|>.12, p<.05$; for $|r|>.17, p<.01$; for $|r|>.23, p<.001$.

Table 5. Regression Summary Statistics

\begin{tabular}{||l|l|l|l|l|c||}
\hline & & & Criterion Measures & & \\
\cline { 2 - 6 } & $\begin{array}{c}\text { Desire to } \\
\text { Return Home }\end{array}$ & $\begin{array}{c}\text { Positive } \\
\text { Emotions }\end{array}$ & $\begin{array}{c}\text { Optimism } \\
\text { about Peace }\end{array}$ & $\begin{array}{c}\text { Negative } \\
\text { Reception }\end{array}$ & $\begin{array}{c}\text { Anticipated } \\
\text { Problems }\end{array}$ \\
\hline Vulnerability B & $-.17^{* *}$ & $-.19^{* *}$ & .03 & .01 & $.37^{* * *}$ \\
\hline Injustice B & $-.23^{* *}$ & $-.23^{* *}$ & -.14 & $.30^{* * *}$ & .14 \\
\hline Distrust B & -.09 & $-.21^{* *}$ & $-.22^{* *}$ & $.15^{*}$ & .04 \\
\hline Superiority B & $.36^{* * *}$ & $.38^{* * *}$ & $.28^{* * *}$ & $-.24^{* * *}$ & -.07 \\
\hline Helplessness $B$ & -.02 & -.07 & -.02 & .11 & -.01 \\
\hline$F(5,229)$ & $19.46^{* * *}$ & $36.18^{* * *}$ & $9.41^{* * *}$ & $18.83^{* * *}$ & $13.86^{* * *}$ \\
\hline$R^{2}$ & .30 & .44 & .17 & .29 & .23 \\
\hline
\end{tabular}

Note. $N=235$.

${ }^{*} p<.05 ;{ }^{* *} p<.01 ;{ }^{* *} p<.001$.

$R^{2}=.30[F(5,229)=19.46, p<.001]$. In this model both vulnerability and injustice beliefs in regard to their refugee group made significant unique contributions in predicting a diminished desire to return home, while a conviction about the group's superiority was significantly linked to a greater desire to repatriate.

A similar but even stronger pattern emerged in regard to the model predicting the respondents' emotional reactions to the prospect of returning home, yielding an $R^{2}=.44$ $[F(5,229)=36.18, p<.001]$. Beliefs about group vulnerability, injustice, and superiority again operated in the same manner as in the model predicting desire to return, but a belief that the group should be distrustful was also a significant predictor, associated with more negative emotional reactions when thinking about returning home.

Compared to the prediction of emotional reactions, beliefs about the in-group were significantly but less strongly linked to the refugees' view of the evolving peace process in Sudan: $R^{2}=.17[F(5,229)=9.41, p<.001]$. In this model only two beliefs made significant independent contributions. A belief in the group's superiority was linked to greater optimism about the peace process while the distrust 
belief was associated with a less positive assessment of the prospects for peace.

The five-belief model also explained nearly one-third of the variance in the criterion measure assessing whether the respondents expected a negative reception upon returning home to Sudan: $R^{2}=.29[F(5,229)=18.83, p<.001]$. In this model, the injustice belief made the largest unique contribution and, along with the distrust belief, was linked to greater expectations that the group would encounter hostility back home in Sudan. In contrast, the superiority belief was associated with a diminished expectation that the refugees would be faced with animosity or resentment upon their return.

The final criterion measure was the extent to which the refugees were concerned about encountering various problems upon their return home. The IGBI belief predictors produced an $R^{2}=.23[F(5,229)=13.86, p<.001]$, accounting for almost one-quarter of the variance in this measure. However, the vulnerability belief was the only one of the five that was significantly linked to these concerns, with those holding stronger vulnerability beliefs reporting greater worries.

\section{Discussion}

The vast majority of our respondents reported that they very much wanted to return home to Sudan, even though they simultaneously acknowledged that they would in all likelihood face significant challenges posed by inadequate security, mines, roads in disrepair, limited educational opportunities, likely financial difficulties, and limited access to potable water. This eagerness to repatriate, perhaps even more surprising following the death of John Garang, speaks to the strength and resiliency of these refugees and to the profound meaning of "home" and the powerful sentiments attached to it. By and large, our respondents were predominantly elated at the prospect of returning, they were hopeful that the peace process would move forward successfully, and they expected to be well-received by those they had left behind. At the same time, it should be noted that fewer than half of the respondents actually expected to return to Sudan over the next twelve months, and in fact the initial UNHCR program in December 2005 proved to be disappointing in the relative paucity of refugees who actually left Kakuma for Sudan.

Our investigation of whether the five belief domains highlighted by Eidelson and Eidelson are useful for understanding how refugees view repatriation yielded promising preliminary results. ${ }^{24}$ As hypothesized, four of the core beliefs - about group vulnerability, injustice, distrust, and helplessness upon returning home-were linked to a diminished desire for repatriation, and to more negative assessments about the peace process and the reception they would receive in Sudan (and indeed these beliefs tended to instead support a preference for resettlement elsewhere). In contrast, across our survey measures a strong belief in their refugee group's superiority was consistently linked with respondents' greater desire to repatriate and a more optimistic perspective on how events would unfold once back home. Speculatively, this may suggest that these refugees were confident that their group could successfully stake its claims and emerge "on top" in the new Sudan, perhaps in part because of skills and experience obtained while at Kakuma. This positive image of their group may serve these prospective returnees well-in contrast, for example, to convictions of group helplessness-but in-group biases in other contexts have regularly been linked with derogation of outgroups and hostility toward them. ${ }^{25}$ This potential "dark side" of superiority beliefs and group pride may warrant close attention as harbingers of renewed intergroup conflict following repatriation.

An important question should be raised here: Do the refugees' beliefs about their group reflect accurate assessments of the circumstances they will face in Sudan or are they subjective distortions involving either overestimates or underestimates of the challenges they will confront? Since there was significant variation among the respondents in their IGBI responses, it would be valuable to know whose convictions were more closely aligned with the "facts on the ground" in Sudan. Our survey measures were prospective in nature, and they do not provide an answer in this regard. However, what is clear is that the refugees' beliefs were strongly linked to individual differences among them in how they viewed the prospect of repatriation. Assessments of these beliefs in relation to "objective" information about circumstances awaiting refugees back home may therefore be a fruitful avenue for intervention by counsellors and others in positions of responsibility for repatriation programs. Group or individual discussions may provide opportunities to explore-and in some cases "correct" (in either direction)—refugees' important convictions about issues over group (or personal) vulnerability, injustice, distrust, superiority, and helplessness. It is also worth noting that the same five core beliefs may also be important after returning home in regard to how successfully the refugees reintegrate into the community they had left behind.

From a methodological perspective, the IndividualGroup Belief Inventory was adapted for this survey to focus on the refugees' beliefs in regard to what it might be like for them-as a group - to return home. Time available for survey administration did not allow us to collect additional IGBI-related data, but it would have been interesting to also learn more about how the refugees viewed both the pros- 
pect of resettlement elsewhere and their current situation in Kakuma in regard to issues of vulnerability, injustice, distrust, superiority, and helplessness. The strength of these beliefs could then have been compared with the beliefs about returning to Sudan to determine whether attitudes toward repatriation in part reflected an implicit cost-benefit analysis of the merits of going home along these five key dimensions. In addition, collecting IGBI data regarding the refugees' beliefs about their own personal worlds (i.e., rather than their convictions about their group) might have been valuable. This would have allowed a comparison of whether beliefs about the self or the group were more important in determining the respondents' perspectives on repatriation.

Certain limitations of our study should be highlighted. First, our survey data were based entirely on self-report and are therefore subject to the concerns associated with this approach. In addition, the reliability coefficients for several of our measures were not as high as would be desirable. Similarly, our analyses are correlational in nature, and therefore issues of causality in regard to relationships among variables cannot be demonstrated. However, some relationships are more plausible than others, and it is our judgment that beliefs about vulnerability, injustice, distrust, helplessness, and superiority may indeed serve as causal influences on judgments about repatriation. At the same time, the limits of the survey include the fact that time and other considerations prevented collection of other data that might bear directly on the relationships found. For example, we did not gather information on why individual refugees had left Sudan or on the lives they had led before fleeing. Finally, it should be noted that women were underrepresented in our survey (women comprise approximately 50 per cent of the Kakuma population, but only 32 per cent of this sample). This may have occurred because all of the counsellors who volunteered to assist with this research were male, and it can be difficult for Sudanese men to approach Sudanese women. Most of the Kakuma counsellors are in fact male, because women tend to have a lower level of education (e.g., counsellors are required to speak English) and they tend to have more outside-of-work commitments than the men (e.g., taking care of the home and family).

Caution is also in order when considering generalization of our findings to other refugee settings. While not unique, the Kakuma camp has its distinctive features - as does every camp and every group of refugees. As one example, many of the refugees in Kakuma have been there for many years. Those minors who came in 1992 and who were not resettled in the United States have grown up in the camp, and in many cases they now have children of their own who have never set foot in Sudan. Their knowledge of Sudan, therefore, may be unrealistic and perhaps idealistic. However, the SPLA has had a significant presence and influence in the camp, so in some ways there has continued to be a strong connection between Kakuma and South Sudan. Since the CPA was signed, many of the SPLA commanders who were in Kakuma have been summoned back to Sudan to take up posts in the new government. Kakuma is very close to the Sudanese border, and there has been continual movement between the two; refugees might return to Sudan for a short period if a family member in Sudan is sick, or if there is a family problem that they have to deal with there. They then return to Kakuma. Finally, there are many cases of families, or occasionally unaccompanied children, coming to Kakuma so that the children could benefit from the education in the camp.

Taken as a whole, we think that the findings reported here merit serious attention and further research, including in other refugee contexts. At the same time, we are also cognizant of the constraints and challenges present in usefully applying psychological models in the realm of humanitarian assistance. In this regard, Ager and Loughry have identified two key issues of particular relevance to our work. ${ }^{26}$ First, psychology is often perceived as primarily concerned with the internal states and behaviours of individuals, rather than with large populations and the environmental factors that impact them (the focus of most humanitarian relief efforts). Here we believe that our approach attempts to help bridge these gaps. Indeed, among the important beliefs that individuals hold are their convictions about those very groups to which they belong. These group-focused beliefs-in this specific instance, beliefs about the circumstances facing prospective returnees-can be quite broad in their influence, and they can affect both individual and collective responses to external events. Second, in its often quixotic search for "universal" principles of human behaviour, psychological analysis can fail to recognize the realities of "cultural specificity." Here we aim to confront this issue head-on, precisely by exploring whether beliefs about vulnerability, injustice, distrust, superiority, and helplessness - with local variations in salience and modes of expression-have cross-cultural applicability and relevance for humanitarian workers assisting refugees in diverse settings.

\section{Notes}

1. See Alastair Ager, ed., Refugees: Perspectives on the Experience of Forced Migration (London: Continuum, 1999); Maryanne Loughry and Alastair Ager, The Refugee Experience: A Psychosocial Training Module (Oxford: Refugee Studies Centre, 2001); The Sphere Project, Humanitarian Charter and Mini- 
mum Standards in Disaster Response (Geneva: The Sphere Project, 2004).

2. Tania Ghanem, When Forced Migrants Return "Home": The Psychosocial Difficulties Returnees Encounter in the Reintegration Process (RSC Working Paper No. 16, Refugee Studies Centre, University of Oxford, 2003).

3. See Assefaw Bariangaber, "The Refugee Experience: Understanding the Dynamics of Refugee Repatriation in Eritrea," Journal of Third World Studies 18 (2001), http://www.looksma rtmiddleeast.com/p/articles/mi_qa3821/is_200110/ai_n895 7088 (accessed September 12, 2006); Giorgia Dona' and John Berry, "Refugee Acculturation and Re-Acculturation," in Refugees: Perspectives On The Experience Of Forced Migration, ed. A. Ager (London: Pinter Press, 1999).

4. Barbara Harrell-Bond and Erica Gaston, "Repatriation and 'Home' Experiences of Other Refugees," <http://www .shaml.org/agenda/2004/march/papers/barbara_paper.htm> (accessed September 12, 2006).

5. Ibid, 5 .

6. UNHCR, Regional Logistics Plan for Repatriation to Sudan (Geneva: UNHCR, 2004).

7. Roy J. Eidelson and Judy I. Eidelson, "Dangerous Ideas: Five Beliefs That Propel Groups Toward Conflict," American Psychologist 58 (2003): 182-192.

8. Ibid.

9. Carlos Martin Beristain, Humanitarian Aid Work: A Critical Approach (Philadelphia: University of Pennsylvania Press, 2006).

10. Aaron Beck, Gary Emery, and Ruth L. Greenberg, Anxiety Disorders and Phobias: A Cognitive Perspective (New York: Basic Books, 1985).

11. Donald L. Horowitz, Ethnic Groups in Conflict (Berkeley, CA: University of California Press, 1985).

12 Marilyn B. Brewer and Rupert J. Brown, "Intergroup Relations," in Handbook Of Social Psychology, ed. D. T. Gilbert, S. T. Fiske, and G. Lindzey (New York: McGraw-Hill, 1998).

13. Ervin Staub, The Roots of Evil: The Origins of Genocide and Other Group Violence (New York: Cambridge University Press, 1989).

14. See Donald T. Campbell, "Stereotypes and Perception of Group Differences," American Psychologist 22 (1967): 812-829; Robert A. Levine and Donald T. Campbell, Ethnocentrism: Theories of Conflict, Ethnic Attitudes and Group Behavior (New York: John Wiley, 1972).

15. Dina Esposito and Bathsheba Crocker, To Guarantee the Peace: An Action Strategy for Post-Conflict Sudan (Washington, DC: Center for Strategic and International Studies, 2005).

16. Levine and Campbell.
17. James Sidanius, "The Psychology of Group Conflict and the Dynamics of Oppression: A Social Dominance Perspective," in Explorations in Political Psychology, ed. S. Iyengar and W. McGuire (Durham, NC: Duke University Press, 1993).

18. See Lynn Abramson, Martin Seligman, and John Teasdale, "Learned Helplessness in Humans: Critique and Reformulation," Journal of Abnormal Psychology 87 (1978): 49-74.

19. See Albert Bandura, "Self-Efficacy: Toward a Unifying Theory of Behavioral Change," Psychological Review 84 (1977): 191-215; Albert Bandura, Self-Efficacy: The Exercise of Control (New York: W.H. Freeman, 1997).

20. See Roy J. Eidelson, "Measuring Parallel Beliefs about Self and Group: Development and Validation of the Individual-Group Belief Inventory” (unpublished manuscript); Roy J. Eidelson and Mary D. Plummer, "Self and Nation: A Comparison of Americans' Beliefs before and after 9/11," Peace and Conflict: Journal of Peace Psychology 11 (2005): 153-175.

21. See Roy J. Eidelson, "Multi-Level Beliefs as Predictors of Life Satisfaction, Group Identification, and Support for the War on Terrorism" (manuscript under review).

22. Jeannie Annan, Lucia Castelli, Anne Devreux, Giovanni Galli, Hilary Haworth, and Mary Ann Kerins, Training Manual for Community Volunteer Counsellors (Kampala, Uganda: Avsi, 2000).

23. UNHCR.

24. Eidelson and Eidelson.

25. See Miles Hewstone, Mark Rubin, and Hazel Willis, "Intergroup Bias,” Annual Review of Psychology 53 (2002): 575-604.

26. Alastair Ager and Maryanne Loughry, "Psychology and Humanitarian Assistance," Journal of Humanitarian Assistance, http://www.jha.ac/articles/a131.htm (accessed September 12, 2006).

Roy J. Eidelson is president of Eidelson Consulting, Bala Cynwyd, Pennsylvania. Rebecca Horn is research fellow at the Institute of International Health and Development, Queen Margaret's University, Edinburgh. Both authors contributed equally to this article. The authors wish to thank the Jesuit Refugee Service Kakuma community counsellors who assisted with this research by revising the survey and collecting information from their fellow refugees. We would also like to thank Arancha Garcia del Soto for her very helpful comments on the manuscript. 